\title{
New Records of Bruchidius Spermaphagous Species in Albizia julibrissin and Laburnum anagyroides and Their Parasitoid Complex in Serbia
}

\author{
Renata Gagić Serdar ${ }^{1 凶}$, Ljubodrag Mihajlović ${ }^{2}$, Zoran Poduška ${ }^{1}$, \\ Ilija Đorđević ${ }^{1}$, Goran Češljar ${ }^{1}$, Svetlana Bilibajkić ${ }^{1}$, Tomislav Stefanović ${ }^{1}$, \\ Radovan Nevenić
}

\footnotetext{
${ }^{1}$ Institute of forestry, Kneza Višeslava 3, RS-11030 Belgrade, Serbia

2 Faculty of forestry, Kneza Višeslava 1, RS-11030 Belgrade, Serbia

$\triangle$ Corresponding author: e-mail: katas96@hotmail.com
}

\begin{abstract}
Citation:
GAGIĆ SERDAR R, MIHAJLOVIĆ $\sqcup$, PODUŠKA Z, ĐORĐEVIĆ I, ČEŠLAR G, BILIBAJKIĆ S, STEFANOVIĆ T, NEVENIĆ R 2014 New Records of Bruchidius Spermaphagous Species in Albizia julibrissin and Laburnum anagyroides and Their Parasitoid Complex in Serbia. South-east Eur for 5 (2): 163-170. DOI: http://dx.doi.org/10.15177/seefor.14-13
\end{abstract}

\section{Abstract}

Background and Purpose: Bruchidius villosus feeding in seed of Laburnum anagyroides, and Bruchidius terrenus seed pest of Albizia julibrissin are first recorded and completely new seed-beetle to Serbian Bruchinae fauna. This Chrysomelids which were found in Republic of Serbia during intensive studies from 2012 to 2014 are likely related to a mostly Paleotropical group, including also members of genera Bruchidius, Megabruchidius and Acanthoscellides. These seed-beetles develop in pods of these two woody legumes, widely grown ornamental trees and shrubs. Several recent reports reveal that this species are well established in France, Hungary, and Bulgaria.

Materials and Methods: Bruchine and their legume hosts were observed by extensive field sampling throughout Serbia over three years and by rearing the beetles from the samples in the laboratory. Bruchines and the parasitoids were mass-reared in climate controled rooms under conditions close to those of their area of origin: $12: 12 \mathrm{~L}: \mathrm{D}, 3-23^{\circ} \mathrm{C}$ and $\leq 80 \% \mathrm{RH}$ (depends of host plant ongoing phenology or experimental needs-proof of weevil monophagous feeding preferences). For the purpose of analyzing the observed phenomena (its intensity and relevance), some of the standard methods of statistical analysis and conclusion have been used.

Results: Levels of seeds infestation still in the pods were high and comparable to other studies. Bruchine beetle infestation in the dehiscent fruits of host plants may be greater after the seeds and pods drop to the ground, as bivoltine generation occurs, but this has yet to be tested. Hypotheses on the geographic origin of this new species are also discussed. The effect of native parasitoids occurrence could potentially be interesting, given that their appearance suggest their specialization on the Bruchidius beetle species which is a common seed-predator on the leguminous seeds. 
Conclusions: The establishment of this new species is investigated using both morphological data and idioecological analyses. For this purpose, a methodology was developed to assess weevil field densities in a natural environment. However, this needs to be more carefully tested with a larger sample size and experiments. Significant levels of infested seed, leads to the conclusion that these seed parasites could be an important reducing factor of generative reproducing host plant potential.

Keywords: Bruchine, legumes, weevil, parasitoids, pods, seed predation, Serbia

\section{INTRODUCTION}

The Old World genus Bruchidius Schilsky, 1905 (Coleoptera: Chrysomelidae: Bruchinae), comprises of about 300 species of seed beetles, widespread in the Old World [1]. Some species were introduced with seeds or soil in territories outside their native areal [1, 2]. For European countries 80 species of the genus were recorded [3]. Bruchidius is the most heterogeneous genus within Bruchinae [4]. Recent investigations of it reveal several phylogenetic groups that are associated with host-plant taxonomic groups [5]. Nevertheless, the genus is not divided into smaller genera, because some species are intermediate concerning morphological characters and bionomic [4]. Most Bruchidius species are reported to feed in the larval stage on the seeds of legumes (Fabaceae), Bruchine chrysomelids are economically important pests of agricultural and stored productsworldwide. Albizia julibrissin Durazz (Fabaceae: Faboideae: Genisteae) and Laburnum anagyroides L. (Leguminosae, Genisteae) both are planted as ornamental trees in Serbia. We studied the seed beetles Bruchidius terrenus (Sharp, 1886) and Bruchidius villosus (Fabricius, 1792), which infest the seeds of $A$. julibrissin and $L$. anagyroides, respectively, and their parasitoids, as native entomofauna in progressive adaptation process. Some species are pests due to the losses caused to economically important plants.

\section{Host Plant characteristics}

Laburnum anagyroides Golden chain, or Scotch broom is a densely branched medium shrub ( 1 - $2 \mathrm{~m}$ in its native area), with attractive yellow flowers (16 - $25 \mathrm{~mm}$ ) that bloom between February and July, depending on the locality. This plant mainly grows on acidic soils, in scrubland accompanying oak, beech and pine woodlands up to $2000 \mathrm{~m}$. It is found in clearings on deep, fresh soil in a large part of western Asia and in Europe across to the Canary Islands, including the entire Iberian Peninsula with the exception of provinces with predominantly limestone soils. It has been accidentally introduced to North and South America, Australia, Hawaii and New Zealand as an ornamental plant [6-8]. Scotch broom is dispersed by seeds that fall roughly $2 \mathrm{~m}$ from the parent plant and may be dispersed more widely by other dispersive factors and agents such as ants [9]. Its ballistic seed dispersal mechanism permits a high-potential establishment of new individuals despite its low seed density [10].

Persian silk tree, pink silk tree - Albizia jullibrisin (Durazz., 1772. non sensu Baker, 1876) (Fabales: Fabaceae) are native to Turkey and planted as ornamental trees. It is a popular ornamental tree planted singly, in groups or lining roads throughout Serbia. Also known as "Mimosa", A. julibrissin origin is from Middle and Eastern Asia. In the last three centuries it was introduced as an ornamental tree in many countries in Europe, North America and Asia due to the beauty of its flowers, fern-like leaves and umbrella-like canopy [11].

\section{MATERIAL AND METHODS}

L. anagyroides and $A$. jullibrisin seed pods were collected at the many localities in 2012, 2013 and 2014. Pods were held in the laboratory in plastic boxes and transparent bags until the emergence of adult beetles and parasitoids. Each sampled population of pods and/or seeds 
was put in a bag connected to a clear bottle or tube, following Fursov [12], and kept under semi-natural room conditions - as it is in the regions where collections were made. Emerging weevils and its parasitoids trapped in the bottles were collected daily for a month and weekly later on until no more adults emerged. Weevil's adults were identified by external morphological traits. The insect specimens and part of plant specimens were deposited at the Institute of Forestry, Belgrade and Faculty of Forestry, Belgrade. We extensively reviewed the published work for weevils associated with studied host plants and their geographical distribution to study host ranges of the beetles. Ripe pods of $A$. julibrissin were collected from several isolated trees in October 2013 and from the following several localities in municipality of Ruma, Deteline and Kudos city parts. Additional material was collected in April 2014 from Ruma (Vojvodina). The material was stored in plastic boxes in laboratory conditions. In the periods June October 2013 and May-June 2014 emer-gence of adult seed beetles was observed. The level of damage caused by the larvae was established in Northern Serbian population. For this purpose, 300 pods of Mimosa were collected; seeds were extracted and observed for emergence holes. Whole seeds were dissected for estimating if they are infested or not. Bruchids were identified after Borowiec [1], Hoebeke et al. [3] and Morimoto [5] and deposited in the author's collection.
Bruchine beetle specimens had emerged from the seeds of legume host plants (Table 1), and mean level of infested seed explored for the localities in Serbia are present in Tables 1 and 2. There are also data about insect stocks cultures bionomic and life cycle developments collect by seed dissection (100 seed per locality). In the laboratory, weevils and the primary parasitoids were massreared in climate controled rooms under conditions close to those of their area of origin: $12: 12 \mathrm{~L}: \mathrm{D}, 3-23^{\circ} \mathrm{C}$ and $\leq 80 \% \mathrm{RH}$ (depends on host plant ongoing phenology or experimental needs-proof of weevil monopha-gous or else feeding preferences). Percentages of total pre-dispersal and post-dispersal (in reinfested material), makes the-se insects serious host plant suppression candi-dates. Their bionomic were monitored by conti-nuous infested seed collecting, its disection and observed also in correlation with host specificity ranged from monophagy (at least ecological monophagy) to possible oligophagy. On the basis of presence/ absence data we tested the null hypothesis assuming that plant taxa and seed consuming weevil species form congruent phyletic relations at the species level [7, 13]. For this purpose, pods of $L$. anagyroides were collected in April 2012 and 2014, than in 2013 during May and August and in April 2014; 300 seeds were also extracted and observed for emergence holes during spring, April, May and June in 2014.

TABLE 1. Host plant and seed beetles native range, sampling localities and sampling date in Serbia

\begin{tabular}{|c|c|c|c|}
\hline & Host plant & Seed beetle & $\begin{array}{l}\text { Sampling localities } \\
\text { and sampling date }\end{array}$ \\
\hline & Albizia julibrissin & Bruchidius terrenus & \multirow{2}{*}{$\begin{array}{l}\text { Ruma } \\
\text { 1. Kudos (August 2012; } \\
\text { June - Octobar 2013); } \\
\text { 2. Deteline } \\
\text { (August 2013; April 2014) }\end{array}$} \\
\hline \multirow[t]{2}{*}{$\begin{array}{l}\text { Native } \\
\text { range }\end{array}$} & $\begin{array}{l}\text { Southwestern and } \\
\text { Eastern Asia }\end{array}$ & Eastern Asia & \\
\hline & Laburnum anagyroides & Bruchidius villosus & \multirow{2}{*}{$\begin{array}{l}\text { 1. Belgrade - Bezanijska kosa } \\
\text { (April 2014) } \\
\text { 2. Belgrade, Cukarica } \\
\text { (May 2012; May, August } \\
\text { 2013) } \\
\text { 3. Novi Sad, City Fair (April 2014) }\end{array}$} \\
\hline $\begin{array}{l}\text { Native } \\
\text { range }\end{array}$ & $\begin{array}{c}\text { Mountains of Southern } \\
\text { Europe from France to } \\
\text { the Balkan Peninsula }\end{array}$ & Native European range & \\
\hline
\end{tabular}




\section{RESULTS}

\section{Insect stocks}

Bruchidius terrenus (Sharp, 1886) is native to eastern Palaearctic region, where it is considered as an important pest of $A$. julibrissin [11]. Morimoto [5] reported Robinia pseudoacacia (L.) and Acacia confuse Merr. as hosts of $B$. terrenus too. Recently, $B$. terrenus was recorded as adventive species in seven southeastern states of USA $[3,11]$. The same authors gave a key for identification of North American Bruchidius species, as well as diagnosis, re-description and seasonal history of $B$. terrenus. In this paper, $B$. terrenus is firstly recorded to the Serbian fauna. The level of damage on seeds of host-plant $A$. julibrissin was investigated in laboratory conditions (Figure 1).

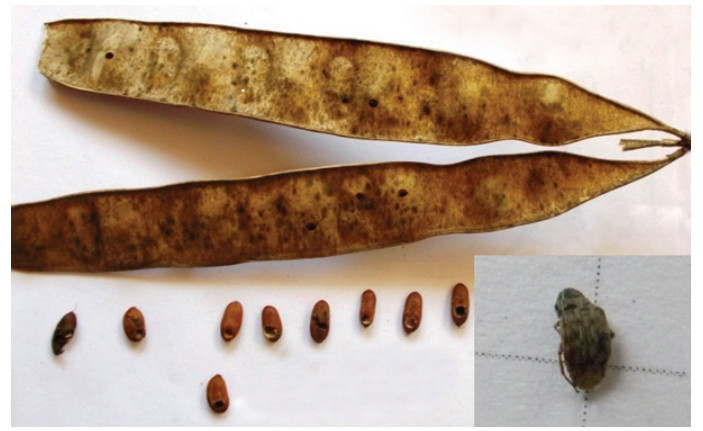

FIGURE 1. Bruchidius terrenus in Albizia jullibrisin, damaged pods, seeds and adult insect (Orig.)

Bruchidius villosus (Fabricius, 1792) is first recorded and completely new to Serbian fauna as specialist feeding in seeds of $L$. anagyroides. We use an indirect method to address the issue of the existence of seed beetles in this popular ornamental and decorative important leguminous woody species in Republic of Serbia. The value of the system lies in the accuracy of host affiliations. Indication of (Fabaceae host plant vs. Bruchine seed predator) - pairs existence, scientifically examined and geographically established, all in numerous previous research, was a lead for insect detection, so their further ecology investigation. Bruchine and their legu- me hosts were observed by extensive field sampling throughout Serbia over three years and by rearing the beetles from the samples in the laboratory. Golden chainas host plants was the subject of pod material sampling [14.]. Our findings were recognized as imagoes and larvae, as seed predators $-B$. villosus and their reared parasitoid complex.

\section{Seasonal History and Habits}

The seasonal history and habits of $B$. terrenus are based mainly on observations by the original collector, supplemented by reference to the biology of $B$. villosus [8].Overwintered, sexually immature adults most likely emerge in late spring and disperse to mimosa where they attain sexual maturity by feeding on pollen. In 2013 adults were first found in June while surveying for the beetle. The latest observation of an adult in the field was mid-August 2013. Mimosa trees flower in Serbia from May through August and the fruits (pods) mature from September to November. Oviposition begins when green pods are forming, probably in early July. Pods ripen from late Aug to Nov and begin to disintegrate soon after but remain on the trees into winter. Female's lay eggs individually (in clusters) on the young pods and cement them in place. Eggs probably hatch in 1-2 weeks, the larvae emerging from the underside of the egg and tunneling into the developing pod. A neonate larva burrows through the pod wall into a soft green seed. Unhatched eggs were still observed on the outside of pods in late July 2013. By mid-August, late instars were found in seeds. During an examination of several trees samples in September 2013, found seeds heavily infested ( $>80 \%$ examined), whereas seeds of these same trees in Sep 2012 were only slightly infested ( $<5 \%$ examined). Pupation occurs within a seed inside the closed pod. The pupation period probably takes from 10 to 20 days. New generation adults chew through the seed coat and then chew through the pod coat to escape. Adults emerged indoors from early to late Sep from infested pods collected in Ruma (first author's personal observation). Adult emergence holes were observed on old seed pods collected in early Sep 2013. New adults, after emergence, 
probably feed on pollen in the fall if flowers are still available. Adults probably overwinter near host trees in plant litter. Based on collecting in 2012 and 2013, adults are found on the host from early to late June to mid-Septembar, so $B$. terrenus appears to be univoltine in Serbia.

The adults of the predispersal $B$. villosus emerge from seeds of $L$. anagiroides and pro- bably other overwintering sites such as the surface of immature pods. Larvae enter through the pod wall and feed on developing seeds. By mid-August, larvae complete development and pupate, and adults emerge from open pods at the end of August or overwinter within seed of closed pods on the plant. $B$. vilosus appears to be univoltine, also, in Serbia.

TABLE 2. Host plant seed infestation cause's and results in percentage (\%) with total number of reared insects for two months laboratory observation period

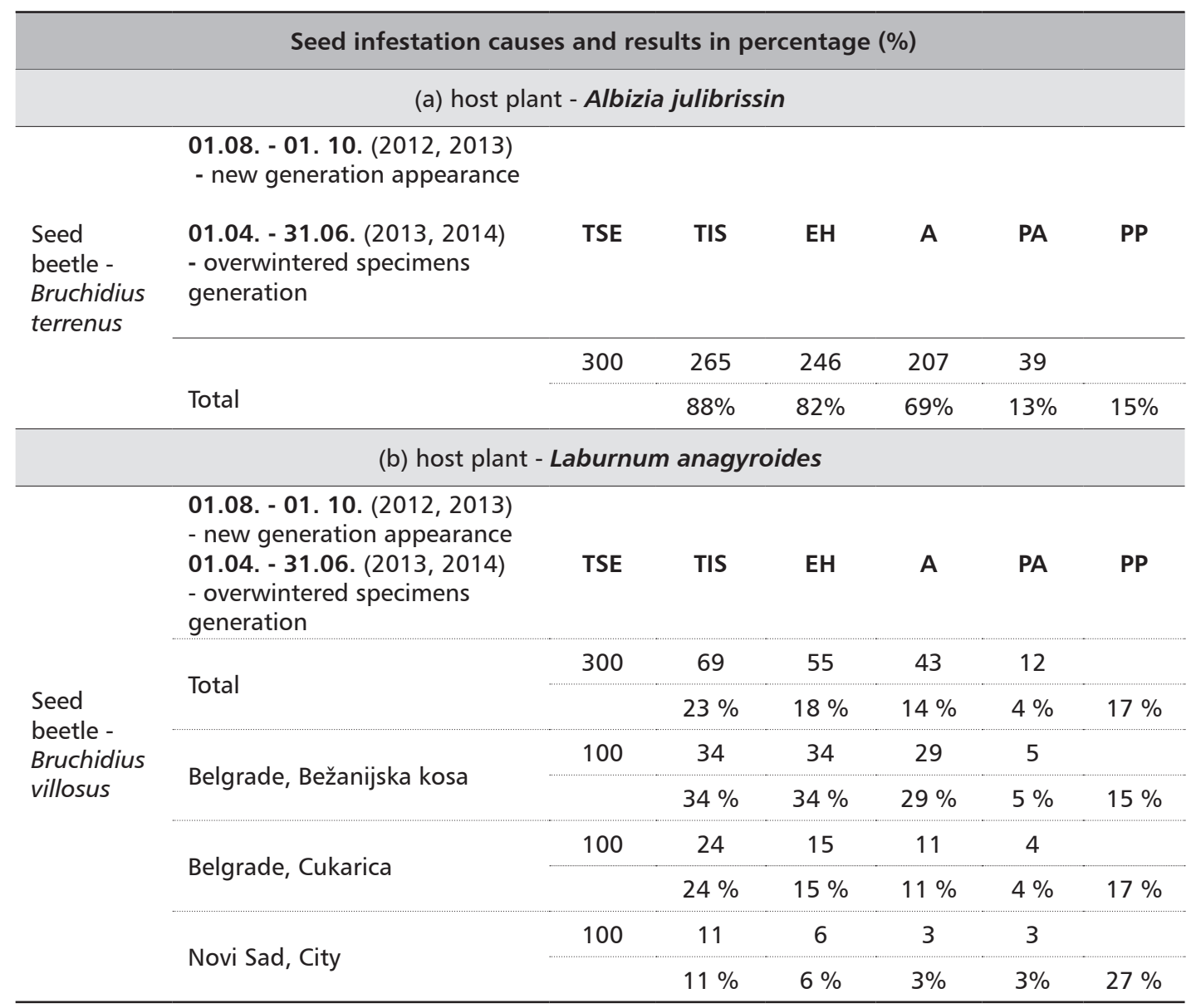

Table notes and legend:

(a) Emergence of the seed beetle Bruchidius terrenus from seeds of Albizia julibrissin with emergence of beetle parasitoids (Eupelmid and Braconid) from $B$. terrenus.

(b) Emergence of the seed beetle Bruchidius villosus from seeds of Laburnum anagyroides with emergence of its parasitoids (Pteromalid, Eupelmid, Eulophid and Braconid).

TSE - total seeds examined; TIS - total infested seeds and percentage of infested seeds; EH - number of seeds with emergence holes; A - number of adults; PA - Number of parasitoids (pteromalid, eupelmid, eulophid); PP Number of parasitoids (PA) divided with total infested seeds (TIS) (in percentage) 


\section{DISCUSSION}

The dispersal methods used by host plants lead some predispersive predator insects such as Bruchinae to develop a clear specificity in their host plants. In the case of Fabaceae, there is an insect-plant synchronization of biological cycles in which the end of the larval growth stage coincides with the pod dehiscence, the point when the seeds are ejected some distance from the plant, and with them, the mature larvae or recently formed imagoes (as in the case of the Bruchidius genera, respectively) [15-17]. Their occupation of the seed until its ejection at maturity explains the strategies used by insects to consume resources and at the same time avoid interspecific competition with other predispersive predator insects growing in certain parts of the seed $[16,18]$.

L. anagyroides L. (Leguminosae, Genisteae) is a broom species of European origin introduced both accidentally and as an ornamental plant to Australia, New Zealand and America, where it is classified as a noxious invasive species. One of its main seed pests is $B$. villosus, a weevil with a Palearctic distribution and which has been introduced to United States and New Zealand as a biological control agent [19]. Factors influencing the insect's choice of oviposition location are crucial for the plant's reproductive success [20]. We examined Bruchidius seed predation on the two legume host plants, in the Republic of Serbia, during climate change environmentally close to wide European Mediterranean region conditions. Future experimental and observational studies are needed to clarify the ecology of host utilization and parasitoid accumulation process of effective bio control of the invading legumes that has become a pantropic species (Table 3).

Hoebeke et al. (2009) [3] reported about $90 \%$ of seeds of some $A$. julibrissin trees in USA were infested with $B$. terrenus. We also, found seeds of this plant species heavily infested with $B$. terrenus - $88 \%$ (Table 1), an Asian seed specialist of $A$. julibrissin that occurs widely in the eastern Palearctic Region, North America, Bulgaria $[3,21]$. According to Stojanova [22] the presence of its host plant, an appropriate climate, and the absence of natural enemies are conditions favorable for fast and successful invasion by $B$. terrenus in new territories outside its native range. All this is confirmed by our results opening some new research, such as native parasitoid fauna adaptation to introduced weevil [23]. Nature of this should be tested intensively with a goal of new idioecological relation recognition, biodiversity comparable studies, with special

TABLE 3. Parasitoid complex as potential biological threatening agents for seed pests

Insect

Eupelmu spp. and Anastatus spp.

(Hymenoptera: Chalcidoidea: Eupelmidae)

Pteromalid wasps

(Hymenoptera: Chalcidoidea: Pteromalidae)

Tetrastichus spp.

(Hymenoptera: Chalcidoidea: Eulophidae)

Braconidwasps (Hymenoptera: Braconidae)
Biology and host preference of pod pests

Ectoparasi toids of $\boldsymbol{B}$. terrenus and

$B$.villosus larvae

\section{Ectoparasitoids of $\boldsymbol{B}$. terrenus and}

B. villosus larvae

Encompass (here) B. terrenus and

B. villosus parasitoids of the first and second order, so it is needed to proceed to the research in order to determine their status hyper-parasitism

Reared specimens as $\boldsymbol{B}$. terrenus and $\boldsymbol{B}$. villosus larvae parasitoids. Investigation needs to be continued with a goal of getting more specimens, data, status confirmation and species determination 
emphasis on new formed intro or interspecies mutualism linkages on Serbian territory.

$B$. terrenus might have been similarly introduced to Serbia with mimosa nursery stock. This seed predator might become a pest of mimosa in landscape plantings and could even be considered a beneficial addition to our fauna by those who regard mimosa as an invasive species and, therefore, an undesirable plant [24].

\section{Acknowledgments}

The study was carried out within the Institute of forestry, Belgrade-Project TP-31070: "The development of technological methods in forestry in order to attain optimal forest cover", financed by the Republic of Serbia - Ministry of Education and Science. Professor Ljubodrag Mihajlović, PhD, Forest Protection Cathedra, Faculty of Forestry, in Belgrade had determinate insect specimens and provided the experimental and theoretical guidance proposals.

\section{REFERENCES}

1. KINGSOLVER JM 2004 Handbook of the Bruchidae of the United States and Canada (Insecta, Coleoptera), Volume 1. United States Department of Agriculture, Agricultural Research Service, Washington, DC, United States of America, Technical Bulletin 1912, 324 p. URL: http://www. ars.usda.gov/is/np/Bruchidae/BruchidaeVol1.pdf (25 February 2014)

2. FAUNA EUROPAEA version 2.1.URL: http://www. faunaeur.org (22 February 2010)

3. HOEBEKE ER, WHEELER Jr AG, KINGSOLVER JM, STEPHAN DL 2009 First North American records of the east palearctic seed beetle Bruchidius terrenus (Coleoptera: Chrysomelidae: Bruchinae), a specialist on mimosa (Albizia julibrissin, Fabaceae). Fla Entomol 92 (3): 434-440

4. BOROWIEC L 1987 The genera of seed-beetles (Coleoptera, Bruchidae). Pol J Entomol 57: 3-207

5. MORIMOTO K 1990 A Synopsis of the Bruchid Fauna of Japan. In: Fujii K, Gatehouse AMR, Johnson CD, Mitchel R, Yoshida T (eds) Bruchids and Legumes: Economics, Ecology and Coevolution, Proceedings of the Second International Symposium on Bruchids and Legumes, Okayama, Japan, 6-9 September 1989. Kluwer Academic Publishers, Dordrecht, The Netherlands, pp 131-140. DOI: http://dx.doi.org/10.1007/978-94-009-2005-7_15

6. REDMON SG, FORREST TG, MARKIN GP 2000 Biology of Bruchidius villosus (Coleoptera: Bruchidae) on Scotch broom in North Carolina. Fla Entomol 83 (3): 242-253

7. WIKIPEDIA 2014 Albizia julibrissin. URL: http:/l en.wikipedia.org/wiki/Albizia_julibrissin (9 June 2014)

8. RODRIGUEZ E, PECO B, GURREA MP 2012 Effect of Scotch broom, Cytisus scoparius, pod size and patch density on Exapion fuscirostre (Coleoptera, Apionidae) seed weevil oviposition. Aust J Entomol 51: 127-132. DOI: http://dx.doi.org/10.1111/ j.1440-6055.2011.00848.x

9. MALO JE 2004 Potential ballistic dispersal of Cytisus scoparius (Fabaceae) seeds. Aust J Bot 52 (5): 653-658. DOI: http://dx.doi.org/10.1071/ BT03162

10. REES M, PAYNTER Q 1997 Biological control of Scotch broom: modelling the determinants of abundance and the potential impact of introduced insect herbivores. J Appl Ecol 34 (5): 1203-1221. DOI: http://dx.doi.org/10.2307/2405232

11. ZHENG $H, W U Y$, DING J, BINION D, FU W, REARDON R 2006 Invasive Plants of Asian Origin Established in the United States and their Natural Enemies, Volume 1. United States Department of Agriculture, Forest Service, Morgantown, West Virginia, United States of America, Forest Health Technology Enterprise Team, 147 p. URL: http:// www.fs.fed.us/foresthealth/technology/pdfs/ IPAOv1ed2.pdf (25 February 2014)

12. FURSOV VN 200 How to Collect Entomophagous Insects [Collecting, rearing and preservation of entomophagous insects (Hymenoptera Parasitica)] (in Russian). Schmalhausen Institute of Zoology of National Academy of Sciences of Ukraine, Logos Publisher, Kiev, Ukraine, $68 \mathrm{p}$

13. GAGIĆ SERDAR R, PODUŠKA $Z$, ĐORĐEVIĆ I, ČEŠLAR G, BILIBAJKIĆ S, RAKONJAC U, NEVENIĆ $R$ 2013 Suppression of indigo bush with pod pests. Arc Biol Sci 65 (2): 801-806 
14. FERRERAS AE, FUNES G, GALETTO L 2014 The role of seed germination in the invasion process of Honey locust (Gleditsia triacanthos L., Fabaceae): comparison with a native confamilial. Plant Spec Biol. DOI: http://dx.doi.org/10.1111/1442$\underline{1984.12041}$

15. SZENTESI Á 2006 Pre-dispersal seed predation by Bruchidius villosus (Coleoptera, Bruchidae) in Laburnum anagyroides (Fabaceae, Genisteae). Communyti Ecol 7 (1): 13-22. DOI: http://dx.doi. org/10.1556/ComEc.7.2006.1.2

16. JERMY T, SZENTESI Á 2003 Evolutionary aspects of host plant specialization - a study on bruchids (Coleoptera: Bruchidae). Oikos 101 (1): 196204. DOI: http://dx.doi.org/10.1034/j.1600$\underline{0706.2003 .11918 . x}$

17. DELOBEL $B$, DELOBEL A 2006 Dietary specialization in European species groups of seed beetles (Coleoptera: Bruchidae: Bruchinae). Oecologia 149 (3): 428-443. DOI: http://dx.doi.org/10.1007/ s00442-006-0461-9

18. GYÖRGY Z 2007 To the biology of the honey locust seed beetle, Megabruchidius tonkineus (Pic, 1904) (Coleoptera: Chrysomelidae: Bruchinae). Folia Entomol Hung 68: 89-96.
19. TUDA M 2007 Applied evolutionary ecology of insects of the subfamily Bruchinae (Coleoptera: Chrysomelidae). Appl Entomol Zool 42 (3): $337-$ 346. DOI: http://dx.doi.org/10.1303/aez.2007.337

20. VAN KLINKEN RD 2005 Total annual seed loss on a perennial legume through predation by insects: The importance of within-season seed and seed feeder dynamics. Austral Ecol 30 (4): 414-425. DOI: http://dx.doi.org/10.1111/j.14429993.2005.01483.x

21. LI-ZHONG H2OO2 List of Chinese Insects Vol II. Sun Yat-sen University Press, Guangzhou, China, 612 p

22. STOJANOVAA2010 Seed beetleBruchidiusterrenus (Sharp) (Coleoptera: Chrysomelidae: Bruchinae) - New invasive species to the Bulgarian fauna. Biotechnol Biotec Eq 24 (1): 646-647. DOI: http:// dx.doi.org/ 10.1080/13102818.2010.10817914

23. TORCHIN ME, LAFFERTY KD, DOBSON AP, McKENZIE VJ, KURIS AM 2003 Introduced species and their missing parasites. Nature 421: 628-630. DOI: http://dx.doi.org/10.1038/nature01346

24. SZENTESI Á, WINK M 1991 Fate of quinolizidine alkaloids through three trophic levels: Laburnum anagyroides (Leguminosae) and associated organisms. J Chem Ecol 17 (8): 1557-1573. DOI: http://dx.doi.org/10.1007/BF00984688 